\title{
A Project Crashing Strategy Considering Contract Clauses and Quality Considerations: An Illustrative Example
}

\author{
Gul Polat ${ }^{1}$, Firat Dogu Akin ${ }^{2}$, Harun Turkoglu³ and Atilla Damci ${ }^{4}$ \\ 1 Istanbul Technical University, Istanbul, Turkey, polatgu@itu.edu.tr \\ 2 Istanbul Technical University, Istanbul, Turkey, akinf@itu.edu.tr \\ 3 Istanbul Technical University, Istanbul, Turkey, hturkoglu@itu.edu.tr \\ 4 Istanbul Technical University, Istanbul, Turkey, damcia@itu.edu.tr
}

\begin{abstract}
Project crashing, a.k.a. project compressing or time-cost trade-off, is an important aspect of managing construction projects. Project crashing can be defined as the time-cost optimization technique, which aims to compress the total project duration with the least incremental cost. In real life problems, the quality is affected when some activities are crashed. This effect may be in a positive or negative way. In addition, there may be strict contract clauses regarding the project duration in terms of early finish bonus and penalty. In this study, a mathematical integer linear programming optimization model is developed using Visual Basic Programming Language integrated with Excel Solver add-in, in order to evaluate different strategies for project execution considering time, cost and quality concerns. Moreover, the developed model takes into account the relationship between crashing cost, early finish bonus, and penalty cost. The proposed model enables project managers to select the most appropriate project crashing strategy at the beginning of the project. An illustrative example is also presented in order to show how the proposed approach can be implemented in real cases.
\end{abstract}

(C) 2020 The Authors. Published by Budapest University of Technology and Economics \& Diamond Congress Ltd Peer-review under responsibility of the Scientific Committee of the Creative Construction Conference 2020.

Keywords: contract clauses, illustrative example, integer linear programming, project crashing, quality considerations

\section{Introduction}

In the construction industry, all project parties, i.e., owners, design team, contractors, suppliers, etc., are obligated to fulfil their responsibilities specified in the contract clauses. A project's success mainly depends on how much these parties fulfil their responsibilities in order to meet the project objectives in terms of time, cost and quality requirements [1]. There is a relationship between these objectives. One way of shortening the project duration is the project crashing. Project crashing is a useful technique, which allocates additional resources, e.g., utilizing more efficient equipment or hiring more workers, for the critical activities to accelerate their durations with the possible lowest cost [2].

The large majority of the researchers deal with solving the relationship between time-cost [3-18], whereas the remainders deal with not only time-cost but also quality [19-28]. When reviewing the studies, which address time-cost-quality trade-off problem, it can be seen that quality is considered only as a threshold $[20,23]$. Few number of studies claim that project crashing may bring about an additional cost for the satisfaction of required quality level through corrective/preventive actions $[5,21,22]$. Moreover, only a few number of studies considered the contract clauses regarding the project duration in terms of delay penalty and early finish bonus $[8,9,29]$. However, these studies generally neglect the quality aspect. 
Crashing activities has an impact on their quality level in a positive or negative way. If this impact is in a negative way, some corrective and/or preventive actions should be taken in order to satisfy the expected quality level, which may increase the overall project cost. On the other hand, if this impact is in a positive way, the exposition to the risk may decrease, which in turn may decrease the quality cost. Therefore, there is a need for a study, which considers time-cost trade-off problem as well as the effects of crashing on quality and the strict contract clauses regarding the project duration, e.g., penalty cost and early finish bonus.

This study aims to fulfil this gap through developing a tool, which automates project crashing considering not only time-cost trade-off but also its impact on quality and contract clauses in terms of penalty cost and early finish bonus. In order to demonstrate how the developed model can be used in real cases, an illustrative example consisting of 18 activities was used.

\section{The proposed model}

For the calculations of relationships of proposed model, Critical Path Method (CPM), which is firstly introduced to solve the "practical" business problems, is used [30]. The original CPM model aimed to finding the minimum cost of a project for all possible project durations [31], so it a useful method for the project crashing process. The proposed model mainly consists of four main steps, which are briefly explained below:

Step 1: In this step, the inputs of the developed model are specified. These inputs include definition of the activities, total number of activities, their normal durations, normal (direct) costs, predecessors and successors of activities, maximum allowable crash times, daily crashing costs of activities, daily indirect cost of the project, the impact of crashing the activity on quality (i.e., threat or opportunity), the quality cost of crashing of the activity for 1 day, the contract duration, penalty cost, and early finish bonus. The inputs of the proposed model are presented in Table 1.

Table 1. The inputs of the proposed model

\begin{tabular}{ll}
\hline Notation & Definition \\
\hline$i$ & Predecessor of activity $j$ \\
$j$ & Successor of activity $i$ \\
$T_{n d i}$ & Total number of activities in the project \\
$C_{n c i}$ & Normal duration of activity $i$ \\
$U_{a c i}$ & Normal (direct) cost of activity $i$ \\
$C_{c c i}$ & Maximum allowable crash time of activity $i$ \\
$C_{i c}$ & Daily crashing cost of activity $i$ \\
$Q(T o r O)_{i}$ & Daily indirect cost of the project \\
$C_{q t i}$ & Impact of crashing the activity $i$ on quality (i.e., threat (T) or opportunity $(\mathrm{O}))(+1$ for T, -1 for O) \\
$T_{d}$ & Quality cost of crashing activity $i$ for 1 day \\
$C_{p}$ & Contract duration \\
$C_{\text {efb }}$ & Daily penalty cost due to the delay on the contract duration \\
\hline
\end{tabular}

Step 2: In this step, two constraints are defined. The first constraint ensures that the crash time of an activity cannot excess the maximum allowable crash time assigned for this activity. The second constraint prevents violating the predecessor-successor relationships between activities.

Step 3: In this step, some transitional outputs are computed. The transitional outputs include actual project completion time, total normal (direct) cost (Eq. 1), total indirect cost (Eq. 2), the number of crashed days for each activity, total crashing cost (Eq. 3), total quality cost (Eq. 4), total penalty cost in the case of delay, if applicable (Eq. 5), and total early finish bonus that decreases the total project cost in the case of completing the project earlier than the contract duration (Eq. 6), if applicable. The transitional outputs of the proposed model are presented in Table 2. 
Table 2. Transitional outputs of the proposed model

\begin{tabular}{ll}
\hline Notation & Definition \\
\hline$T_{c}$ & Actual project completion duration \\
$C_{n c t}$ & Total normal (direct) cost \\
$C_{i c t}$ & Total indirect cost \\
$Z_{i}$ & The number of crashed days for activity $i$ \\
$C_{c c t}$ & Total crashing cost \\
$C_{Q t}$ & Total quality cost \\
$C_{p t}$ & Total penalty cost \\
$C_{\text {eftbt }}$ & Total early finish bonus \\
\hline
\end{tabular}

The equations used to compute the transitional outputs are presented in Equations 1-6.

$$
\begin{aligned}
C_{n c t} & =\sum_{i=1}^{N} C_{n c i} \\
C_{i c t} & =C_{i c} \times T_{c} \\
C_{c c t} & =\sum_{i=1}^{N} Z_{i} \times C_{c c i} \\
C_{Q t} & =\sum_{i=1}^{N} Z_{i} \times Q(\text { TorO })_{i} \times C_{q t i} \\
C_{p t} & =\left\{\begin{array}{ll}
\left(T_{c}-T_{d}\right) \times C_{p} & \text {,if } \mathrm{T}_{\mathrm{c}}>\mathrm{T}_{\mathrm{d}} \\
0 & \text {,if } \mathrm{T}_{\mathrm{c}} \leq \mathrm{T}_{\mathrm{d}}
\end{array}\right\} \\
C_{e f f t} & =\left\{\begin{array}{ll}
\left(T_{d}-T_{c}\right) \times C_{e f b} & \text {,if } \mathrm{T}_{\mathrm{d}}>\mathrm{T}_{\mathrm{c}} \\
0 & \text {,if } \mathrm{T}_{\mathrm{d}} \leq \mathrm{T}_{\mathrm{c}}
\end{array}\right\}
\end{aligned}
$$

Step 4: In this step, the objective function is determined. For this purpose, first the total project cost (Eq. 7) is calculated, which is the sum of total direct cost, total indirect cost, total crashing cost, total quality cost, total penalty cost, and total early finish bonus.

$$
C_{p c}=C_{n c t}+C_{i c t}+C_{c c t}+C_{Q t}+C_{p t}-C_{e f b t}
$$

The objective function is the minimization of the total project cost (Eq. 8).

$$
\min \left(C_{p c}\right)
$$

\section{Illustrative example}

The applicability of the proposed approach is demonstrated using a network consisting of 18 activities [32]. The network of the illustrative example is presented in Figure 1.

The inputs for the illustrative example is presented in Table 3. The activities $A 1, A 2, A 4, A 5, A 7, A 8, A 9, A 11$, $A 13, A 14, A 16$, and $A 17$ are considered to be threats, whereas the activities $A 3, A 6, A 10, A 12, A 15$, and $A 18$ are considered to be opportunities in terms of quality. The total project completion duration is found to be 105 days. The contract duration is accepted as 95 days. Daily penalty cost is considered to be $\$ 300$, whereas $\$ 250$ of daily early finish bonus will be paid to the contractor in the case that the project finishes earlier than the contract duration. Finally, the daily indirect cost is determined as $\$ 400$. 


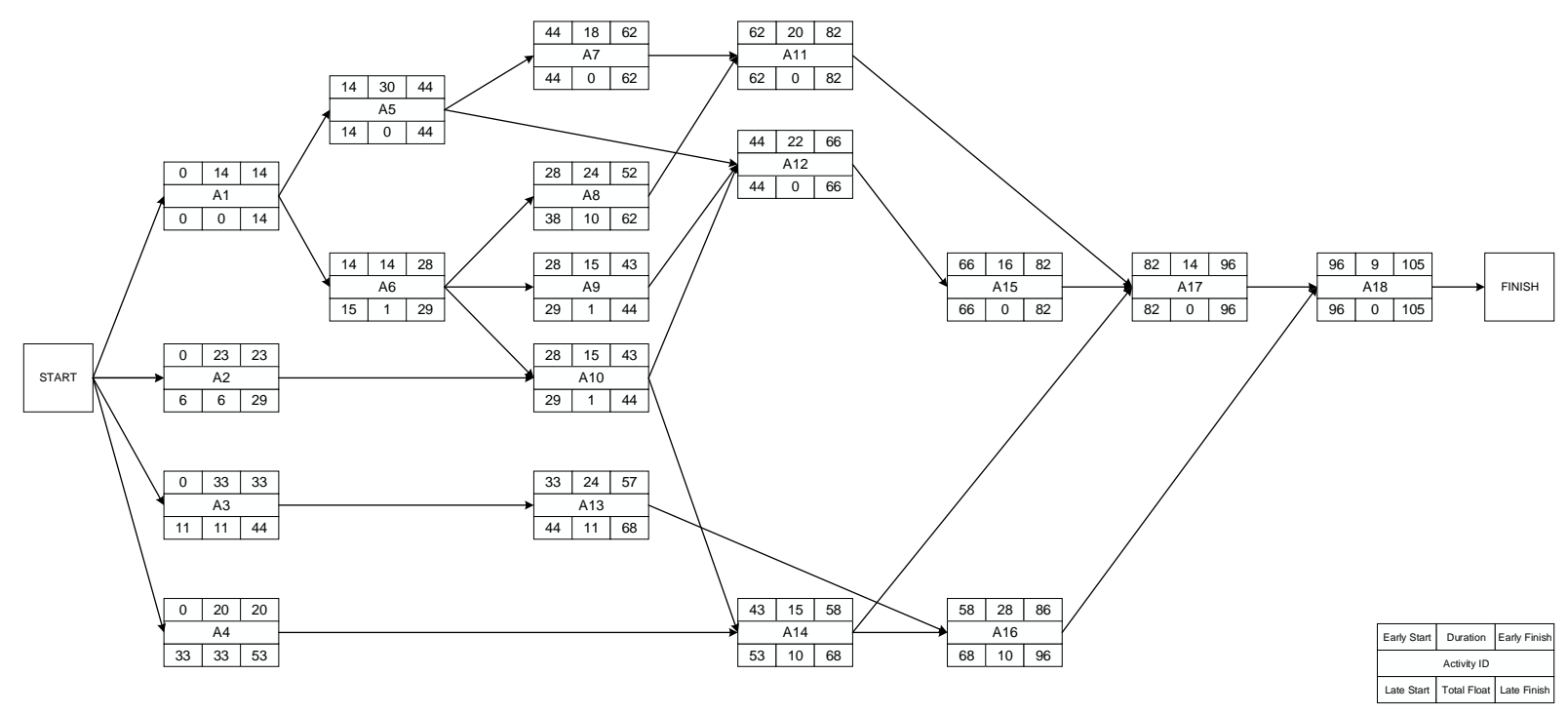

Fig. 1. Network for illustrative example.

The actual project completion duration is found to be 105 days.

Table 3. Inputs of the illustrative example.

\begin{tabular}{|c|c|c|c|c|c|c|c|c|}
\hline Activity ID & $\begin{array}{l}\text { Immediate } \\
\text { Predecessor } \\
\text { Activity }\end{array}$ & $\begin{array}{l}\text { Duration } \\
\text { (Day) }\end{array}$ & $\begin{array}{l}\text { Max. Crash } \\
\text { Times (Day) }\end{array}$ & $\begin{array}{l}\text { Normal } \\
\text { (Direct) Cost } \\
(\$)\end{array}$ & $\begin{array}{l}\text { Daily Normal } \\
\text { Cost (\$/Day) }\end{array}$ & $\begin{array}{l}\text { Daily } \\
\text { Crashing } \\
\text { Cost (\$/day) }\end{array}$ & $\begin{array}{l}\text { Quality Cost } \\
\text { (\$/day) }\end{array}$ & $\begin{array}{l}\text { Threat or } \\
\text { Opportunity } \\
\text { (Binary) }\end{array}$ \\
\hline $\mathrm{A} 1$ & Start & 14 & 4 & $20,000.00$ & $1,428.57$ & 285.71 & 114.29 & $T$ \\
\hline A2 & Start & 23 & 5 & $19,000.00$ & 826.09 & 165.22 & 66.09 & $\mathrm{~T}$ \\
\hline A3 & Start & 33 & 8 & $23,000.00$ & 696.97 & 139.39 & 27.88 & 0 \\
\hline A4 & Start & 20 & 4 & $24,000.00$ & $1,200.00$ & 240.00 & 96.00 & $T$ \\
\hline A5 & $\mathrm{A} 1$ & 30 & 6 & $11,000.00$ & 366.67 & 73.33 & 29.33 & $\mathrm{~T}$ \\
\hline A6 & $\mathrm{A} 1$ & 14 & 3 & $20,000.00$ & $1,428.57$ & 285.71 & 57.14 & O \\
\hline A7 & A5 & 18 & 6 & $22,000.00$ & $1,222.22$ & 244.44 & 97.78 & $\mathrm{~T}$ \\
\hline A8 & A6 & 24 & 7 & $25,000.00$ & $1,041.67$ & 208.33 & 83.33 & $T$ \\
\hline A9 & A6 & 15 & 3 & $35,000.00$ & 2,333.33 & 466.67 & 186.67 & $\mathrm{~T}$ \\
\hline A10 & $\mathrm{A} 2, \mathrm{~A} 6$ & 15 & 3 & $42,000.00$ & $2,800.00$ & 560.00 & 112.00 & O \\
\hline A11 & $\mathrm{A} 7, \mathrm{~A} 8$ & 20 & 4 & $41,000.00$ & $2,050.00$ & 410.00 & 164.00 & $\mathrm{~T}$ \\
\hline A12 & $\mathrm{A} 5, \mathrm{~A} 9, \mathrm{~A} 10$ & 22 & 5 & $35,000.00$ & $1,590.91$ & 318.18 & 63.64 & 0 \\
\hline A13 & A3 & 24 & 8 & $42,000.00$ & $1,750.00$ & 350.00 & 140.00 & $\mathrm{~T}$ \\
\hline A14 & $\mathrm{A} 4, \mathrm{~A} 10$ & 15 & 5 & $43,000.00$ & $2,866.67$ & 573.33 & 229.33 & $\mathrm{~T}$ \\
\hline A15 & $\mathrm{A} 12$ & 16 & 0 & $39,000.00$ & $2,437.50$ & 487.50 & 97.50 & O \\
\hline A16 & $\mathrm{A} 13, \mathrm{~A} 14$ & 28 & 8 & $24,000.00$ & 857.14 & 171.43 & 68.57 & $\mathrm{~T}$ \\
\hline A17 & $\mathrm{A} 11, \mathrm{~A} 14, \mathrm{~A} 15$ & 14 & 3 & $15,000.00$ & $1,071.43$ & 214.29 & 85.71 & $\mathrm{~T}$ \\
\hline A18 & $\mathrm{A} 16, \mathrm{~A} 17$ & 9 & 2 & $20,000.00$ & 2,222.22 & 444.44 & 88.89 & $\mathrm{O}$ \\
\hline
\end{tabular}

The proposed model was developed using Visual Basic Programming Language integrated with Excel Solver add-in. Having inputted the required information, the developed model automatically generates the schedule, determines the critical activities, and selects critical activity/activities for crashing. In the developed model, the project duration is shortened day by day. The process is repeated until a feasible solution cannot be found.

Two different scenarios were applied in the illustrative example. In the first scenario, it is assumed that crashing an activity does not have an impact on the quality level of the activity. The crashed activities and their crashing costs in the first scenario are presented in Table 4. 
Proceedings of the Creative Construction e-Conference (2020) 040 Available online at e-2020.creative-construction-conference.com/proceedings/

Table 4. Crashed activities and their crashing costs in the first scenario, where the impact on quality is not considered.

\begin{tabular}{|c|c|c|c|c|c|c|c|}
\hline $\begin{array}{l}\text { Project } \\
\text { Duration (Day) }\end{array}$ & $\begin{array}{l}\text { Sequence of } \\
\text { Activities } \\
\text { Crashed }\end{array}$ & $\begin{array}{l}\text { Total } \\
\text { Normal } \\
\text { Cost }(\$) \\
(1)\end{array}$ & $\begin{array}{l}\text { Total } \\
\text { Indirect } \\
\text { Cost }(\$) \\
(2)\end{array}$ & $\begin{array}{l}\text { Cumulative } \\
\text { Crashing Cost } \\
(\$) \\
(3)\end{array}$ & $\begin{array}{l}\text { Penalty } \\
\text { Cost } \\
(\$) \\
(4) \\
\end{array}$ & $\begin{array}{l}\text { Early } \\
\text { Finish } \\
\text { Bonus (\$) } \\
(5)\end{array}$ & $\begin{array}{l}\text { Cumulative } \\
\text { Total Project } \\
\text { Cost }(\$) \\
(1+2+3+4-5) \\
\end{array}$ \\
\hline 105 & - & $500,000.00$ & $42,000.00$ & 0.00 & $3,000.00$ & 0.00 & $545,000.00$ \\
\hline 104 & A5 & $500,000.00$ & $41,600.00$ & 73.33 & $2,700.00$ & 0.00 & $544,373.33$ \\
\hline 103 & A17 & $500,000.00$ & $41,200.00$ & 287.62 & $2,400.00$ & 0.00 & $543,887.62$ \\
\hline 102 & $\mathrm{~A} 17$ & $500,000.00$ & $40,800.00$ & 501.90 & $2,100.00$ & 0.00 & $543,401.90$ \\
\hline 101 & $\mathrm{~A} 17$ & $500,000.00$ & $40,400.00$ & 716.19 & $1,800.00$ & 0.00 & $542,916.19$ \\
\hline 100 & $\mathrm{~A} 1$ & $500,000.00$ & $40,000.00$ & $1,001.90$ & $1,500.00$ & 0.00 & $542,501.90$ \\
\hline 99 & $\mathrm{~A} 1$ & $500,000.00$ & $39,600.00$ & $1,287.62$ & $1,200.00$ & 0.00 & $542,087.62$ \\
\hline 98 & $\mathrm{~A} 1$ & $500,000.00$ & $39,200.00$ & $1,573.33$ & 900.00 & 0.00 & $541,673.33$ \\
\hline 97 & $\mathrm{~A} 1$ & $500,000.00$ & $38,800.00$ & $1,859.05$ & 600.00 & 0.00 & $541,259.05$ \\
\hline 96 & $\mathrm{~A} 5, \mathrm{~A} 6$ & $500,000.00$ & $38,400.00$ & $2,218.10$ & 300.00 & 0.00 & $540,918.10$ \\
\hline 95 & $\mathrm{~A} 5, \mathrm{~A} 12$ & $500,000.00$ & $38,000.00$ & $2,609.61$ & 0.00 & 0.00 & $540,609.61$ \\
\hline 94 & $\mathrm{~A} 5, \mathrm{~A} 12$ & $500,000.00$ & $37,600.00$ & $3,001.13$ & 0.00 & 250.00 & $540,351.13$ \\
\hline 93 & A18 & $500,000.00$ & $37,200.00$ & $3,445.57$ & 0.00 & 500.00 & $540,145.57$ \\
\hline 92 & A18 & $500,000.00$ & $36,800.00$ & $3,890.01$ & 0.00 & 750.00 & $539,940.01$ \\
\hline 91 & $\mathrm{~A} 3, \mathrm{~A} 5, \mathrm{~A} 12$ & $500,000.00$ & $36,400.00$ & $4,420.92$ & 0.00 & $1,000.00$ & $539,820.92$ \\
\hline 90 & $\mathrm{~A} 3, \mathrm{~A} 5, \mathrm{~A} 12$ & $500,000.00$ & $36,000.00$ & $4,951.83$ & 0.00 & $1,250.00$ & $539,701.83$ \\
\hline 89 & $\mathrm{~A} 3, \mathrm{~A} 7, \mathrm{~A} 12$ & $500,000.00$ & $35,600.00$ & $5,653.85$ & 0.00 & $1,500.00$ & $539,753.85$ \\
\hline 88 & $\mathrm{~A} 2, \mathrm{~A} 3, \mathrm{~A} 6, \mathrm{~A} 7$ & $500,000.00$ & $35,200.00$ & $6,488.62$ & 0.00 & $1,750.00$ & $539,938.62$ \\
\hline 87 & $\mathrm{~A} 2, \mathrm{~A} 3, \mathrm{~A} 6, \mathrm{~A} 7$ & $500,000.00$ & $34,800.00$ & $7,323.39$ & 0.00 & $2,000.00$ & $540,123.39$ \\
\hline 86 & $\mathrm{~A} 3, \mathrm{~A} 7, \mathrm{~A} 9, \mathrm{~A} 10$ & $500,000.00$ & $34,400.00$ & $8,733.90$ & 0.00 & $2,250.00$ & $540,883.90$ \\
\hline 85 & $\mathrm{~A} 3, \mathrm{~A} 7, \mathrm{~A} 9, \mathrm{~A} 10$ & $500,000.00$ & $34,000.00$ & $10,144.40$ & 0.00 & $2,500.00$ & $541,644.40$ \\
\hline
\end{tabular}

In the second scenario, it is assumed that crashing an activity has an impact on the quality level of the activity. The crashed activities and their relevant costs in the second scenario are presented in Table 5.

Table 5. Crashed activities and their relevant costs in the second scenario, where the impact on quality is considered

\begin{tabular}{|c|c|c|c|c|c|c|c|c|}
\hline $\begin{array}{l}\text { Project } \\
\text { Duration } \\
\text { (Day) }\end{array}$ & $\begin{array}{l}\text { Sequence of } \\
\text { Activities } \\
\text { Crashed }\end{array}$ & $\begin{array}{l}\text { Total } \\
\text { Normal } \\
\text { Cost }(\$) \\
(1)\end{array}$ & $\begin{array}{l}\text { Total Indirect } \\
\text { Cost }(\$) \\
(2)\end{array}$ & $\begin{array}{l}\text { Cumulative } \\
\text { Crashing } \\
\text { Cost }(\$) \\
\text { (3) }\end{array}$ & $\begin{array}{l}\text { Cumulative } \\
\text { Quality Cost } \\
(\$) \\
(4)\end{array}$ & $\begin{array}{l}\text { Penalty } \\
\text { Cost } \\
(\$) \\
(5)\end{array}$ & $\begin{array}{l}\text { Early } \\
\text { Finish } \\
\text { Bonus (\$) } \\
(6)\end{array}$ & $\begin{array}{l}\text { Cumulative Total } \\
\text { Project } \\
\text { Cost }(\$) \\
(1+2+3+4+5-6)\end{array}$ \\
\hline 105 & - & $500,000.00$ & $42,000.00$ & 0.00 & 0.00 & $3,000.00$ & 0.00 & $545,000.00$ \\
\hline 104 & A5 & $500,000.00$ & $41,600.00$ & 73.33 & 29.33 & $2,700.00$ & 0.00 & $544,402.67$ \\
\hline 103 & $\mathrm{~A} 17$ & $500,000.00$ & $41,200.00$ & 287.62 & 115.05 & $2,400.00$ & 0.00 & $544,002.67$ \\
\hline 102 & $\mathrm{~A} 17$ & $500,000.00$ & $40,800.00$ & 501.90 & 200.76 & $2,100.00$ & 0.00 & $543,602.67$ \\
\hline 101 & $\mathrm{~A} 17$ & $500,000.00$ & $40,400.00$ & 716.19 & 286.48 & $1,800.00$ & 0.00 & $543,202.67$ \\
\hline 100 & $A 5, A 6$ & $500,000.00$ & $40,000.00$ & $1,075.24$ & 258.67 & $1,500.00$ & 0.00 & $542,833.90$ \\
\hline 99 & $\mathrm{~A} 5, \mathrm{~A} 6$ & $500,000.00$ & $39,600.00$ & $1,434.29$ & 230.86 & $1,200.00$ & 0.00 & $542,465.14$ \\
\hline 98 & $\mathrm{~A} 5, \mathrm{~A} 6$ & $500,000.00$ & $39,200.00$ & $1,793.33$ & 203.05 & 900.00 & 0.00 & $542,096.38$ \\
\hline 97 & A18 & $500,000.00$ & $38,800.00$ & $2,237.78$ & 114.16 & 600.00 & 0.00 & $541,751.94$ \\
\hline 96 & A18 & $500,000.00$ & $38,400.00$ & 2,682.22 & 25.27 & 300.00 & 0.00 & $541,407.49$ \\
\hline 95 & $\mathrm{~A} 5, \mathrm{~A} 12$ & $500,000.00$ & $38,000.00$ & $3,073.74$ & -9.03 & 0.00 & 0.00 & $541,064.70$ \\
\hline 94 & $\mathrm{~A} 5, \mathrm{~A} 12$ & $500,000.00$ & $37,600.00$ & $3,465.25$ & -43.34 & 0.00 & 250.00 & $540,771.92$ \\
\hline 93 & $\mathrm{~A} 1$ & $500,000.00$ & $37,200.00$ & $3,750.97$ & 70.95 & 0.00 & 500.00 & $540,521.92$ \\
\hline 92 & $\mathrm{~A} 1$ & $500,000.00$ & $36,800.00$ & $4,036.68$ & 185.24 & 0.00 & 750.00 & $540,271.92$ \\
\hline 91 & $\mathrm{~A} 3, \mathrm{~A} 7, \mathrm{~A} 12$ & $500,000.00$ & $36,400.00$ & $4,738.70$ & 191.50 & 0.00 & $1,000.00$ & $540,330.20$ \\
\hline 90 & $\mathrm{~A} 3, \mathrm{~A} 7, \mathrm{~A} 12$ & $500,000.00$ & $36,000.00$ & $5,440.72$ & 197.76 & 0.00 & $1,250.00$ & $540,388.48$ \\
\hline
\end{tabular}


Table 5 (continued). Crashed activities and their relevant costs in the second scenario, where the impact on quality is considered

\begin{tabular}{lllllllll}
\hline $\begin{array}{l}\text { Project } \\
\begin{array}{l}\text { Duration } \\
\text { (Day) }\end{array}\end{array}$ & $\begin{array}{l}\text { Sequence of } \\
\text { Activities } \\
\text { Crashed }\end{array}$ & $\begin{array}{l}\text { Total } \\
\text { Normal } \\
\text { Cost }(\$)(1)\end{array}$ & $\begin{array}{l}\text { Total } \\
\text { Indirect } \\
\text { Cost }(\$)(2)\end{array}$ & $\begin{array}{l}\text { Cumulative } \\
\text { Crashing } \\
\text { Cost }(\$) \\
(3)\end{array}$ & $\begin{array}{l}\text { Cumulative } \\
\text { Quality Cost } \\
(\$) \\
(4)\end{array}$ & $\begin{array}{l}\text { Penalty } \\
\text { Cost }(\$) \\
(5)\end{array}$ & $\begin{array}{l}\text { Early Finish } \\
\text { Bonus }(\$) \\
(6)\end{array}$ & $\begin{array}{l}\text { Cumulative Total } \\
\text { Cost }(\$) \\
(1+2+3+4+5-6)\end{array}$ \\
\hline 89 & A3,A7,A12 & $500,000.00$ & $35,600.00$ & $6,142.74$ & 204.02 & 0.00 & $1,500.00$ & $540,446.76$ \\
88 & A1,A2,A3 & $500,000.00$ & $35,200.00$ & $6,733.07$ & 356.52 & 0.00 & $1,750.00$ & $540,539.58$ \\
87 & A1,A2,A3 & $500,000.00$ & $34,800.00$ & $7,323.39$ & 509.01 & 0.00 & $2,000.00$ & $540,632.40$ \\
86 & A3,A7,A9,A10 & $500,000.00$ & $34,400.00$ & $8,733.90$ & 653.58 & 0.00 & $2,250.00$ & $541,537.47$ \\
85 & A3,A7,A9,A10 & $500,000.00$ & $34,000.00$ & $10,144.40$ & 798.14 & 0.00 & $2,500.00$ & $542,442.55$ \\
\hline
\end{tabular}

The total project cost is also affected by the contract clauses related to penalty cost and early finish bonus. Total project costs at different project completion durations based on the findings of different scenarios are compared in Table 6.

Table 6. Total costs at different project completion durations.

\begin{tabular}{|c|c|c|c|c|}
\hline Project Duration (Days) & $\begin{array}{l}\text { Contract } \\
\text { Clauses and } \\
\text { Quality are } \\
\text { not } \\
\text { Considered } \\
\text { (\$) }\end{array}$ & Contract Clauses are not Considered, but Quality Considered (\$) & $\begin{array}{l}\text { Contract } \\
\text { Clauses are } \\
\text { Considered, } \\
\text { but Quality is } \\
\text { not } \\
\text { Considered } \\
\text { (\$) (Scenario } \\
1)\end{array}$ & $\begin{array}{l}\text { Contract } \\
\text { Clauses and } \\
\text { Quality are } \\
\text { Considered } \\
\text { (\$) (Scenario } \\
\text { 2) }\end{array}$ \\
\hline 105 & $542,000.00$ & $542,000.00$ & $545,000.00$ & $545,000.00$ \\
\hline 95 & $540,609.61$ & $541,064.70$ & $540,609.61$ & $541,064.70$ \\
\hline 92 & $540,690.01$ & $541,021.92$ & $539,940.01$ & $540,271.92$ \\
\hline 90 & $540,951.83$ & $541,638.48$ & $539,701.83$ & $540,388.48$ \\
\hline 85 & $544,144.40$ & $544,942.55$ & $541,644.40$ & $542,442.55$ \\
\hline
\end{tabular}

As it can be seen in Table 6, when the contract clauses related to penalty cost and early finish bonus are not considered (columns 2 and 3 in Table 6), the minimum total project cost attained in Days 95 and 92, respectively, since the daily crashing cost is lower than the sum of daily indirect cost and the quality cost (if applicable). On the other hand, when the contract clauses are considered (columns 4 and 5 in Table 6), the minimum total project cost is attained at Days 90 and 92, respectively, due to the contract clauses and decrease in indirect cost. Moreover, when the impact of crashing on the quality level of the activities is not considered (column 4 in Table 6), the total project cost is lower than the one when its impact is considered (column 5 in Table 6). This finding would be different in different cases. This finding also indicates that the impact of crashing on the quality level of the activities should be considered as it directly affects the total project cost and the sequence of the crashed activities.

\section{Conclusion}

Project crashing has been studied by numerous researchers for many years. In most of these studies, the contract clauses related to penalty cost and early finish bonus, and the impact of crashing on both the quality level of the crashed activities and the quality cost are neglected. This study proposes a crashing model, which considers both contract clauses and the impacts of crashing on quality. In order to demonstrate how the proposed model can be employed, an illustrative example was presented. For this purpose, the proposed model was developed using Visual Basic Programming Language integrated with Excel Solver add-in. The results indicated that both the contract clauses and quality considerations have significant influence on total project cost. This study is limited as the illustrative example consists of only eighteen activities. In future studies, the proposed model can be applied in a real-life project. 
Proceedings of the Creative Construction e-Conference (2020) 040

Available online at e-2020.creative-construction-conference.com/proceedings/

\section{References}

[1] J. Bennett, T. Grice, "Procurement systems for building," in Quantity Surveying Techniques: New Directions, P. Brandon Ed. Oxford, U.K.: Blackwell Scienti_c Publications, (1990).

[2] S. Ahipasaoglu, K. Natarajan, D. Shi, "Distributionally robust project crashing with partial or no correlation information". Networks, (2019), 74(1), 79-106. https://doi.org/10.1002/net.21880

[3] H. Csordas, "An overview of the time-cost trade-off problems of project planning", Procedia engineering. (2017), 196 323-326. https://doi.org/10.1016/j.proeng.2017.07.206

[4] A. Katti, M. Darade, "Project Crashing to Solve Time-Cost Trade-Off", SSRG International Journal of Civil Engineering (SSRGIJCE) (2016).

[5] P. Singh, F. Smarandache, D. Chauhan, A. Bhaghel, "A unit based crashing pert network for optimization of software project cost", International Journal of Contemporary Mathematical Science (2015), 10 293-302.

[6] P. Ozor, C. Mbohwa, "A composite cost-time trade-off model for multi-storey project fast tracking", In International Conference on Operations and Supply Chain Management, (2019), Vietnam.

[7] M.A. Haque, N. Ahmad, "Crashing axiom artis installation project by linear programming", Bangladesh Research Publications Journal, (2012), 6(4), 356-362.

[8] A.P. Chassiakos, S.P. Sakellaropoulos, "Time-cost optimization of construction projects with generalized activity constraints", Journal of Construction Engineering and Management, (2005), 131(10), 1115-1124.

[9] K. Shrestha, P. Shrestha, "Optimization of Project Schedule Crashing", In Construction Research Congress. (2016), ASCE.

[10] M. Milenkovic, N. Bojovic, R. Ribeiro, N. Glisovic, "A Fuzzy Simulated Annealing approach for project time-cost tradeoff", Journal Of Intelligent \& Fuzzy Systems, (2012), 23(5), 203-215. https://doi.org/10.3233/ifs-2012-0510

[11] M. Ammar, "Optimization of Project Time-Cost Trade-Off Problem with Discounted Cash Flows", Journal Of Construction Engineering And Management, (2011), 137(1), 65-71. https://doi.org/10.1061/(asce)co.1943-7862.0000256

[12] A. El-kholy, "Time-cost tradeoff analysis considering funding variability and time uncertainty", Alexandria Engineering Journal, (2013), 52, 113-121. https://doi.org/10.1016/j.aej.2012.07.007

[13] P. DE, E. J. Dunne, J. B. Ghosh, C. Wells, "The discrete time-cost tradeoff problem revisited", European Journal Of Operational Research, (1995), 81(2), 225-238. https://doi.org/10.1016/0377-2217(94)00187-h

[14] K. Li, B. Shao, P. Zelbst, "Project Crashing Using Excel Solver: A Simple AON Network Approach", International Journal Of Management \& Information Systems (IJMIS), (2012), 16(2), 177. https://doi.org/10.19030/ijmis.v16i2.6917

[15] S. Erenguc, S. Tufekci, C. Zappe, "Solving time/cost trade-off problems with discounted cash flows using generalized benders decomposition", Naval Research Logistics, (1993), 40(1), 25-50. https://doi.org/10.1002/1520-6750(199302)40:1<25::aidnav3220400103>3.0.co;2-2

[16] E. Demeulemeester, B. D. Reyck, B. Foubert, W. Herroelen, M. Vanhoucke, "New computational results on the discrete time/cost trade-off problem in project networks", Journal Of The Operational Research Society, (1998), 49(11), 1153-1163. HTTPS://doi.org/10.1038/sj.jors.2600634

[17] E. Demeulemeester, W. Herroelen, S. Elmaghraby, "Optimal procedures for the discrete time/cost trade-off problem in project networks", European Journal Of Operational Research, (1996), 88(1), 50-68. https://doi.org/10.1016/0377-2217(94)00181-2

[18] A. Tatar, M. Bilir, R. Sonmez, T. Atan, "A Mixed Integer Model for Optimization of Discrete Time Cost Tradeoff Problem", In Creative Construction Conference, (2016), pp. 478-485. Budapest: Diamond Congress Ltd.

[19] J. Kim, C. Kang, I. Hwang, "A practical approach to project scheduling: considering the potential quality loss cost in the time-cost tradeoff problem", International Journal Of Project Management, (2012), 30(2), 264-272. https://doi.org/10.1016/j.ijproman.2011.05.004

[20] A. Galagali, "Time-Cost-Quality Trade-off in Construction Project Management", International Journal Of Civil Engineering, (2017), 4(8), 24-31. https://doi.org/10.14445/23488352/ijce-v4i8p104

[21] B. Keren, Y. Cohen, "Optimising project performance: the triangular trade-off optimisation approach", International Journal Of Engineering Management And Economics, (2012), 3(1/2), 152. https://doi.org/10.1504/ijeme.2012.048610

[22] N. Hamta, M. Ehsanifar, J. Sarikhani, "Presenting a goal programming model in the time-cost-quality trade-off", International Journal Of Construction Management, (2018), 1-11. https://doi.org/10.1080/15623599.2018.1502930

[23] K. El-Rayes, A. Kandil, "Time-Cost-Quality Trade-Off Analysis for Highway Construction", Journal Of Construction Engineering And Management, (2005), 131(4), 477-486. https://doi.org/10.1061/(asce)0733-9364(2005)131:4(477)

[24] J. Kim, C. Kang, I. Hwang, "Ensuring Quality in Time-Cost Trade-off Problems in Crashing a Project"I In SKISE Autumn Conference, (2020), Kongju-si, Korea.

[25] M. Liberatore, B. Pollack-Johnson, "Improving Project Management Decision Making by Modeling Quality, Time, and Cost Continuously", IEEE Transactions On Engineering Management, (2013), 60(3), 518-528. https://doi.org/10.1109/tem.2012.2219586

[26] S. Mohamad, S. B. Hilmi, M.H. Adenan, I.A Rahman, "'Project crashing impact to labour productivity and quality of work in construction project"', In: The International Conference on Civil and Environmental Engineering Sustainability (IConCEES 2011), 3-5 April (2012), Johor Bahru, Malaysia.

[27] A. Mahmoudi, M. Feylizadeh, "A grey mathematical model for crashing of projects by considering time, cost, quality, risk and law of diminishing returns", Grey Systems: Theory And Application, (2018) 8(3), 272-294. https://doi.org/10.1108/gs-12-2017-0042

[28] M. Feylizadeh, A. Mahmoudi, M. Bagherpour, D. Li, "Project crashing using a fuzzy multi-objective model considering time, cost, quality and risk under fast tracking technique: A case study", Journal Of Intelligent \& Fuzzy Systems, (2018) 35(3), 3615-3631. https://doi.org/10.3233/jifs-18171

[29] Z. Abuwarda, T. Hegazy, "Flexible Activity Relations to Support Optimum Schedule Acceleration", Journal Of Construction Engineering And Management, (2016) 142(11), 06016004. https://doi.org/10.1061/(asce)co.1943-7862.0001193

[30] J.E. Kelley, M.E. Walker, "Critical path planning and scheduling". In: Proceedings of the Eastern Joint Computer Conference, (1959), 1-3 December, Boston, MA, pp. 160-173.

[31] M. Hajdu, S. Isaac, "Sixty years of project planning: history and future". Organization, Technology and Management in Construction: an International Journal, (2016), 8(1), 1499-1510.

[32] W.C. Feng, L. Liu, S.A. Burns, "Using genetic algorithms to solve construction time-cost trade-off problems", Journal of computing in civil engineering, (1997) 11(3), 184-189. 